\title{
STUDY OF BIOLOGICAL AND ECOLOGICAL FEATURES OF PERMANENT ECTOPARASITES OF CATTLE
}

\author{
Iryna Proskurina \\ Department of Veterinary Examination, Microbiology, Zoohygiene \\ and Safety and Quality of Livestock Products ${ }^{1}$ \\ Liudmyla Nahorna $\bowtie$ \\ Department of Veterinary Examination, Microbiology, Zoohygiene \\ and Safety and Quality of Livestock Products ${ }^{1}$ \\ lvn_10@ukr.net \\ ${ }^{1}$ Sumy National Agrarian University \\ 160 Herasyma Kondratieva str., Sumy, Ukraine, 40021
}

$\triangle$ Corresponding author

\begin{abstract}
The aim of the research was to study the epizootological features of bovicolosis and sifunculatosis and to determine their biological features.

Materials and methods. Eight groups of animals were examined, 15 animals in each, including cows, heifers and calves. Groups of calves consisted of 13 heifers and 17 bulls. A total of 103 females and 17 male cattle were examined.

Results. During observations, it was noted that in most cases, certain species of ectoparasites were found on different animals. In the case of their simultaneous parasitism on one animal, populations occupied different parts of the host's body. The causative agents of sifunculatosis (L. vituli) and bovicolosis (B. bovis) were determined.

During the study of epizootological features of sifunculatosis and bovicolosis, attention was paid to the seasonality of the invasion - the minimum intensity of the invasion was observed in the warm season, the maximum - in winter. The extent of invasion among calves reached $100 \%$.

The biological features of ectoparasites were studied. According to the data obtained, it was determined that linognathus are greater than B. bovis at all stages of development. Egg size $0.8-0.9 \mathrm{~mm}$, larvae go through all stages of molting from $0.7 \mathrm{~mm}$ to $3.3 \mathrm{~mm}$, adults reach a size of $3.3-4.0 \mathrm{~mm}$. However, the eggs of B. bovis reached $0.3-0.5 \mathrm{~mm}$, the size of the larvae $0.4-1.0 \mathrm{~mm}$, adults ranged from $1 \mathrm{~mm}$ to $1.8 \mathrm{~mm}$.

Conclusions. It was noted that the intensity of the infestation of bovicolosis and sifunculatosis increases in the cold season. The young are most prone to lesions.

Keywords: ectoparasites, cattle, seasonal dynamics, seasonality, cattle breeding, sifunculatosis, bovicolosis, intensity of invasion.

\section{Introduction}

Cattle breeding is an important branch of agriculture. This is due to the high consumer value of milk, beef and products made from them. One of the main tasks of veterinary medicine is to obtain safe, high-quality and biologically complete products from animals. The growth and volume of industrial and farm production in the livestock industry and the development of the processing industry are directly related to the need to maintain a high level of sanitation in the animal health system.

In the current development of agriculture, the question of controlling the reduction of economic losses caused by livestock parasitic pathogens [1]. One of the reasons for the loss of production is livestock diseases caused by ecto- and endoparasites. Invasive diseases, in particular entomoses are common $[2,3]$. According to industry experts, the damage caused by parasitism of arthropods on cattle is not less than those caused by infectious agents [4, 5]. The epizootic significance of arthropods lies in the transmission of pathogens of many transmissible pathogens to cattle, including anaplasmas [6], rickettsiae, bacteria, spirochetes, piroplasmidas and viruses [7, 8]. Animals are most prone to infection with intensive livestock technologies, if there is a violation
\end{abstract}

DOI: $10.21303 / 2504-5679.2021 .001965$ 
of sanitary and hygienic norms, rules of keeping, feeding and neglect of preventive anti-epizootic measures $[9,10]$. Even with basic veterinary measures, permanent ectoparasites can infect livestock, as animals experience more intense hair growth during the winter stall period. In the absence of sufficient insolation, even this physiological feature of the body contributes to outbreaks of diseases caused by permanent ectoparasites [11, 12]. During the stall period, significant damage to livestock is caused by permanent parasites - lice and hair follicles, which cause sifunculatosis and bovicolosis disease $[13,14]$. Researchers have found that prolonged parasitism of ectoparasites leads to deep and persistent metabolic disorders in animals [15, 16]. This is manifested by a decrease in milk and meat productivity, deterioration of skins, low weight of calves at birth, their lag in growth, loss of growth of fattening animals, and in the case of high intensity of invasion the death of animals $[17,18]$.

The issue of import substitution and food security remains relevant. Therefore, special attention needs to be paid to increasing the own production of quality domestic livestock products. The above indicates the need to study the epizootiology of ectoparasitosis caused by lice and chewing lice of cattle, their biology and seasonal activity.

The aim of the research was to study the epizootological features of bovicolosis and sifunculosis and to determine their biological features.

\section{Materials and methods}

The research was conducted from March 2019 to February 2020 in the conditions of cattle farms of Sumy region. Eight groups of cattle were examined, 15 animals each, including cows, heifers, mating heifers and calves. Groups of calves consisted of 13 heifers and 17 bulls. A total of 103 females and 17 male cattle were subjected to parasitological examination. The distribution of animals into groups was carried out taking into account physiological parameters. Groups of animals of about the same age, weight and the like were formed according to production indicators. The examined animals belonged to the breeds Holstein Black, Ukrainian Black-spotted and Simmental.

All animal studies complied with ARRIVE recommendations and were performed in accordance with the UK Animal Act and EU Directive 2010/63/EU on the protection of animals used for scientific purposes, as amended by Regulation (EU) 2019/1010 and approved by the Bioethics Commission of the Faculty of Veterinary Medicine, Sumy National Agrarian University, No. 4, dated 21.12.2020.

The extent of the invasion was determined by clinical and parasitological examination. Infections of animals with lice and hair follicles and their topography on the body were determined by examination of the skin in the lumbar and croup, between the shoulder blades, dorso-lateral part of the chest, on the chest at the level of the shoulder blades, abdominal area at the level of the shoulder blades, lateral part of the lower back chest, dorsal and lateral parts of the neck, horns, eyes and nose, as well as limbs. The extent of invasion (\%) was calculated by the formula:

$$
\mathrm{EI}=n / N \times 100 \%
$$

where $n$ is the number of infected animals; $N$ is the number of studied animals. The intensity of the invasion was determined by counting the number of parasites (in places of localization with a high concentration of parasites). The calculation was performed on plots with an area of $100 \mathrm{~cm}^{2}$. For these purposes, we used a square frame with a wire that divides the frame into 25 squares. When accounting, the frame was tightly applied to the body of the animal and lined with vaseline oil to avoid creeping ectoparasites from the study area. During the examination of insect-infected animals, attention was paid to the density of the coat, the combing or tousling of the coat, areas with severe alopecia, as well as the tropism of pathogens on the body of animals.

Pathogens were identified by light microscopy in the parasitology department of the Sumy Regional State Laboratory of the State Service of Ukraine for Food Safety and Consumer Protection. Also, in the electron microscopy laboratory of Sumy National Agrarian University, imago siphuncle microscopy was performed by scanning electron microscopy [19, 20]. 


\section{Results}

During the clinical examination of animals of different age groups, areas of alopecia (Fig. 1), wrinkling of the coat and combed wounds were found. Observations showed a pronounced seasonality of the invasion, changes in localization on the body of animals and interspecific relationships of ectoparasites. In most cases, certain species of ectoparasites were found in different animals. In the case of their simultaneous parasitism on one animal, populations occupied different parts of the host's body.

In winter, the extent of infestation with sifunculatosis reached a maximum and amounted to $10-23 \%$ in cows, $14-26 \%$ in heifers and heifers of mating age and covered $100 \%$ of young animals. In bovicolosis, the extent of infestation among cows was 11-26\%, in heifers and heifers of mating age this indicator varied in the range of $15-28 \%$, and in calves the extent of infestation in bovicolosis was in the range of 46-85\%. In the warm season, the extent of sifunculatosis infestation decreased to $8-14 \%$ in cows, $6-13 \%$ in heifers and heifers of mating age, and $15-48 \%$ in calves. The bovicolosis extensive extent of the invasion decreased to $9-16 \%$ in cows, $10-18 \%$ in heifers and heifers of mating age, and $14-23 \%$ in calves.

Insects were easily detected during a thorough examination of the fur of the examined animals (Fig. 2). The maximum intensity of the invasion (Fig. 3) was observed in calves that lagged behind in development and with reduced body weight.

The intensity of the invasion was determined at different times of the year in sifunculatosis (Fig. 4) and bovicolosis (Fig. 5).

In winter, the main sites of localization of sifunculatosis on the bodies of cows, heifers and heifers of mating age were the head and neck, in calves: neck, shoulder, anal fold and croup. Indicators of the number of parasites varied between 16 and 62 specimens and 25-69 specimens per $100 \mathrm{~cm}^{2}$, respectively. B. bovis were localized in the areas of the head, shoulders, sides and croup in cows, heifers and heifers of mating age, in calves - in the upper neck, shoulders, back, sides and croup. The number of insects in these areas reached 7-59 specimens and 5-49 specimens per $100 \mathrm{~cm}^{2}$, respectively.

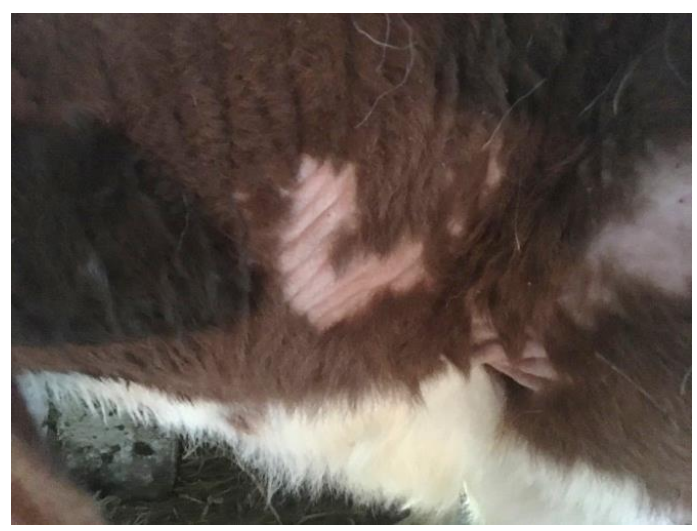

Fig. 1. Areas of alopecia on the body of the animal

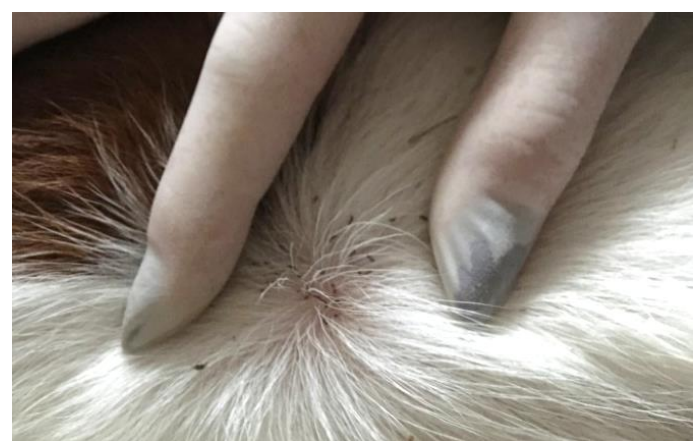

Fig. 2. Colonies of chewing lice of Bovicola bovis 


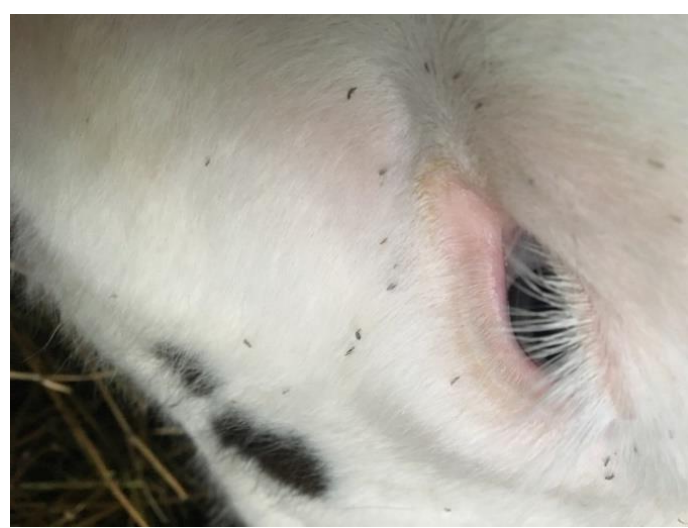

Fig. 3. Linognathus vituli on the head of a calf

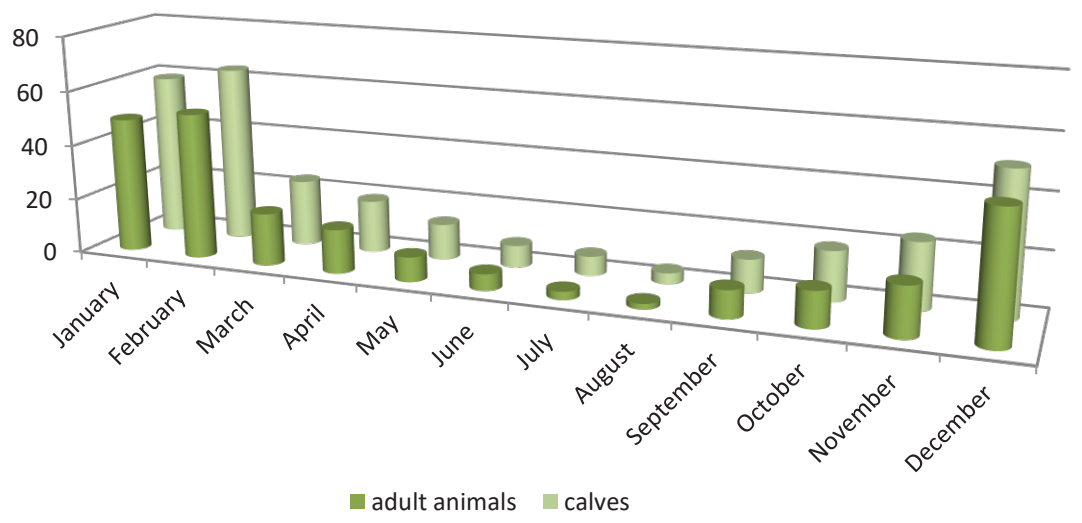

Fig. 4. The average indicator of the intensity of the invasion in the seasonal dynamics of infection of cattle with sifunculatosis (II, sp./100 $\mathrm{cm}^{2}$ )

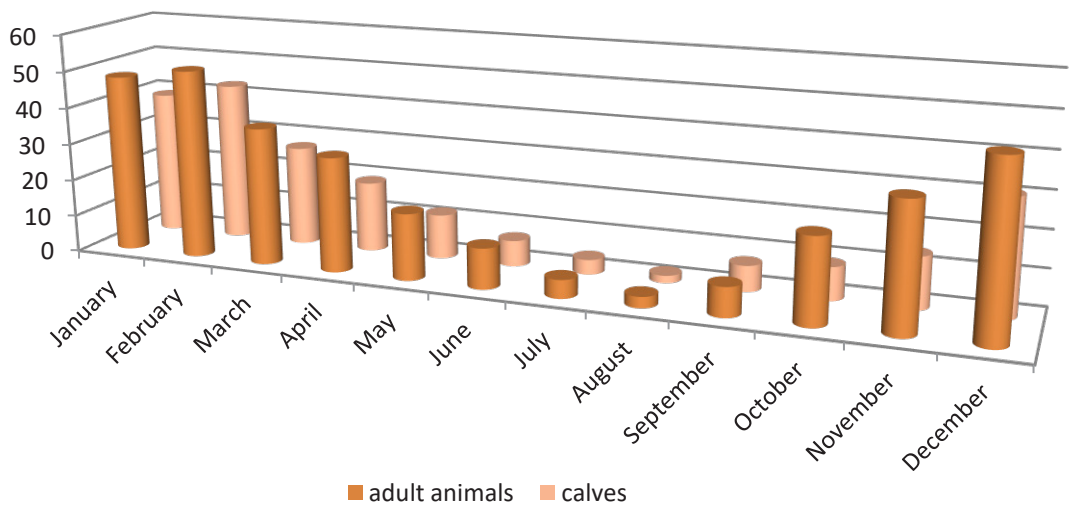

Fig. 5. The average intensity of invasion in the seasonal dynamics of infection of cattle with bovicolosis (II, sp./100 $\mathrm{cm}^{2}$ )

In spring, sifunculatosis were localized at the base of the horns and in the neck of cows, heifers and heifers of mating age. Calves were affected by insects in the neck, back, croup and anal folds. In these areas, the number of lice reached 6-21 specimens and 2-27 specimens per $100 \mathrm{~cm}^{2}$, respectively. At the same time, cows, heifers and heifers of mating age were found in the head, neck, shoulder blades and root of the tail, and in calves - in the upper neck, shoulders, back, sides, groats. The number of B. bovis in these areas varied between 2-42 specimens and 3-29 specimens, respectively, according to the given age groups.

In the warm season there was a decrease in the intensity of infection. This phenomenon is due to the action of sunlight on ectoparasites, shedding of animals and increased immunity of 
cattle in pasture. In the summer months, the insects changed their localization to more closed areas of the host's body (at the base of the horns, ears, in the subscapular areas, groin and on the inside of the limbs) (Fig. 6).

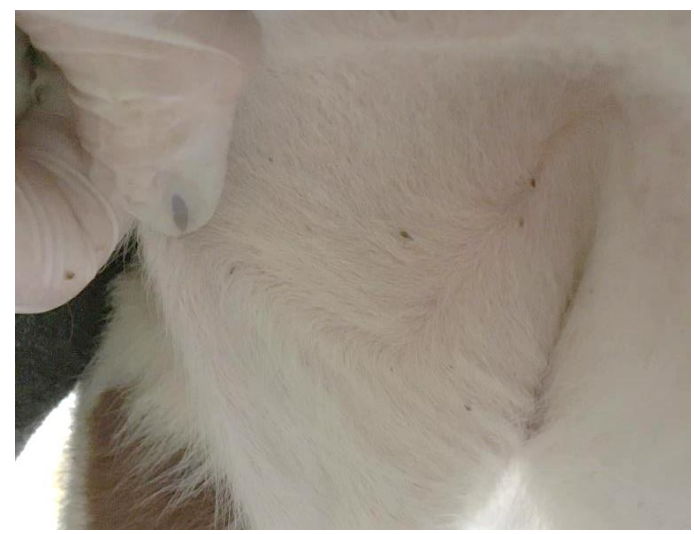

Fig. 6. Linognathus vituli on the inside of the limb

In the autumn months, with the onset of cold weather, sifunculatosis migrate to the base of the horns, nape, neck of cows, heifers and heifers of mating age; on the neck, head, anal fold and sides - in calves. There were 8-21 specimens and 3-36 specimens of insects per $100 \mathrm{~cm}^{2}$ of these plots, respectively.

At the same time, bovicolosis animals were localized on the head, neck, shoulders, sides and groin in cows, heifers and heifers of mating age. On calves, they took the place of the upper neck, shoulders, sides, back and croup. The average number of insects in these areas varied between 2-38 specimens and $6-15$ specimens per $100 \mathrm{~cm}^{2}$, respectively.

The morphology of selected individuals of insects was studied. Linognathus microscopy used the method of scanning electron microscopy (Fig. 7). B. bovis was examined by light microscopy (Fig. 8).

Sifunculatosis were small wingless insects with a length of 1 to $4 \mathrm{~mm}$. They had an elongated-oval body, much larger than the chest and covered with hairs and bristles. Chest is rectangular, short, brown. Contains three pairs of legs, the length of which increases from head to body. The head is narrower and longer than the chest, contains a proboscis of prickly-sucking type.

Detected bovicolosis were small wingless insects ranging in size from 1 to $2 \mathrm{~mm}$. Abdomen brownish-yellow, elongated-oval, segmented, flattened dorso-ventrally and covered with bristles and hairs. The chest consists of three joints, to which are attached three pairs of legs. The head is significantly wider than the chest, contains a proboscis of the rodent type.

In the study of selected ectoparasites, the sizes of individuals of different age groups were established (Table 1).

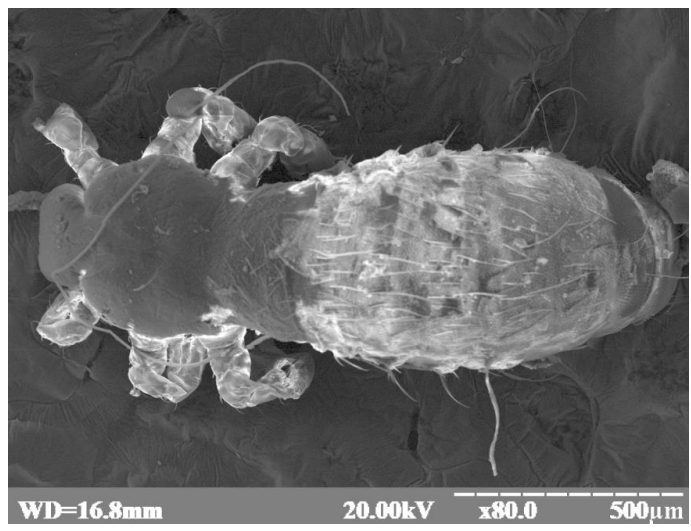

Fig. 7. Imago Linognathus vituli (electron microscopy) 


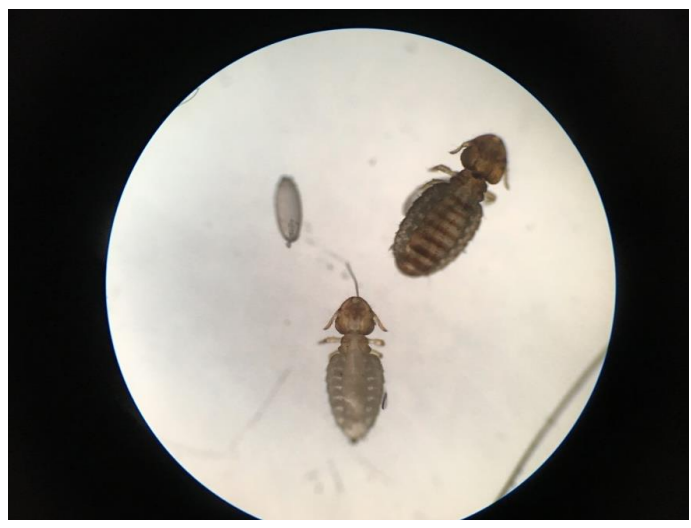

Fig. 8. Bovicola bovis at different stages of development

Table 1

Morphological features of $L$. vituli and B. bovis

\begin{tabular}{cccc}
\hline \multirow{2}{*}{ Type of pathogen } & \multicolumn{3}{c}{ Size, $\mathbf{~ m m}$} \\
\cline { 2 - 4 } & $\mathbf{E g g}$ & Larvae & Imago \\
\hline Linognathus vituli & $0.8-0.9$ & $0.7-3.3$ & $3.3-4.0$ \\
Bovicola bovis & $0.3-0.5$ & $0.4-1.0$ & $1.0-1.8$
\end{tabular}

According to the data obtained, it was determined that Linognathus are greater than B. bovis at all stages of development. Egg size $0.8-0.9 \mathrm{~mm}$, larvae go through all stages of molting from $0.7 \mathrm{~mm}$ to $3.3 \mathrm{~mm}$, adults reach the size of $3.3-4.0 \mathrm{~mm}$. At the same time, B. bovis eggs reached $0.3-0.5 \mathrm{~mm}$, larval size $0.4-1.0 \mathrm{~mm}$, and adults varied from $1 \mathrm{~mm}$ to $1.8 \mathrm{~mm}$.

\section{Discussion}

Studies have shown that young cattle are more prone to ectoparasites. In winter, the extent of infestation for bovicolosis reached $85 \%$, and for sifunculatosis - up to $100 \%$. Meanwhile, in adults, the extent of the invasion reached a maximum of $23-26 \%$ for sifunculatosis and $26-28 \%$ for bovicolosis. During the warm season, the extent of the invasion decreased rapidly. The maximum extent of infestation among young animals was $48 \%$ for sifunculosis and $23 \%$ for bovicolosis. Extensiveness of invasion among adult animals for sifunculatosis reached $13-14 \%$, and for bovicolosis up to $16-18 \%$. In the case of their simultaneous parasitism on one animal, populations occupied different parts of the host's body $[13,17]$.

The main sites of localization of the sifunculatosis were the areas of the head and neck and shoulders, and the B. bovis occupied the areas of the shoulders, sides, back and groin. In the summer months, insects changed the location to more closed areas of the host's body (at the base of the horns, ears, in the subscapular areas, groin and on the inside of the limbs) $[5,16]$.

Pathogens were identified by light and electron microscopy. L. vituli and B. bovis were isolated. Linognathus were small wingless insects with an elongated-oval body, much larger than the chest and covered with hairs and bristles, had a proboscis of prickly-sucking type. B. bovis were small wingless insects with a brownish-yellow belly, elongated-oval shape and covered with bristles and hairs. The head is markedly wider than the chest, contains a proboscis of the gnawing type $[1,18]$.

We compared the morphology of pathogens and found that L. vituli had a larger size at all stages of development.

The obtained results are in agreement with the data of other authors who conducted studies of permanent ectoparasites on cattle.

Study limitations. A limitation of the study is the study of biological and ecological features of a narrow range of pathogens of ectoparasitosis of cattle, however the tasks were performed. 
Prospects for further research. Prospects for further research are to study the epizootic situation with regard to acariasisin farms of different production facilities in the region.

\section{Conclusions}

During the study of epizootological features of sifunculosis and bovicolosis, attention was paid to the seasonality of the invasion - the minimum intensity of the invasion was observed in the warm season, the maximum - in winter. The extent of invasion among calves reached $100 \%$. In February, there is a maximum intensity of invasion among all age groups.

Despite the fact that lice and chewing lice have different structures and occupy different links in the food chain, there have been interpopulation relationships in which ectoparasites did not parasitize on the same animal, and in the case of co-parasitism, occupied different areas on the host body.

\section{Conflict of interest}

The authors declare there is no conflict of interests.

\section{Financing}

The study is part of the research work of the Department of Veterinary Examination, Microbiology, Zoohygiene and Safety and Quality of Livestock Products «Development and improvement of veterinary and sanitary measures to ensure prevention, treatment, productivity and resistance of animals» No. 0119U101389.

\section{References}

[1] Gebreselama, M., Zeru, F., Romha, G. (2014). Identification and Prevalence of Ectoparasites in Cattle and Sheep in and Around Bishoftu Town, Central Ethiopia. Animal and Veterinary Sciences, 2 (4), 124-129. doi: http://oi.org/10.11648/ j.avs.20140204.17

[2] Asnake, F., Yacob, H. T., Hagos, A. (2013). Ectoparasites of small ruminants in three agro-ecological districts of Southern Ethiopia. African Journal of Basic \& Applied Sciences, 5, 47-54.

[3] Pérez de León, A. A., Mitchell, R. D., Watson, D. W. (2020). Ectoparasites of Cattle. Veterinary Clinics of North America: Food Animal Practice, 36 (1), 173-185. doi: http://doi.org/10.1016/j.cvfa.2019.12.004

[4] Mullen, G. R., Durden, L. A. (2019). Medical and Veterinary Entomology. Philadelphia: Saunders, 792. doi: http://doi.org/ 10.1016/c2017-0-00210-0

[5] Rony, S.A., Mondal, M.H., Begum, N., Islam, M.A., Affroze, S. (2010). Epidemiology of ectoparasitic infestations in cattle at Bhawal forest area, Gazipur / Bangl. J. Vet. Med. 8(1). 27-33.

[6] Da Silva, A. S., Lopes, L. S., Diaz, J. D. S., Tonin, A. A., Stefani, L. M., Araújo, D. N. (2013). Lice Outbreak in Buffaloes: Evidence ofAnaplasma marginaleTransmission by Sucking LiceHaematopinus tuberculatus. Journal of Parasitology, 99(3), 546-547. doi: http://doi.org/10.1645/ge-3260.1

[7] Gale, P., Brouwer, A., Ramnial, V., Kelly, L., Kosmider, R., Fooks, A. R., Snary, E. L. (2009). Assessing the impact of climate change on vector-borne viruses in the EU through the elicitation of expert opinion. Epidemiology and Infection, 138 (2), 214-225. doi: http://doi.org/10.1017/s0950268809990367

[8] Larska, M., Kęsik-Maliszewska, J., Kuta, A. (2014). Spread of Schmallenberg virus infections in the ruminants in Poland between 2012 and 2013. Bulletin of the Veterinary Institute in Pulawy, 58 (2), 169-176. doi: http://doi.org/10.2478/bvip-2014-0026

[9] Abubeker, A., Assen, A., Dhuguma, A. (2021). Efficacy evaluation of methanolic extracts of Calpurnia aurea and Schinus molle plants against the cattle lice Linognathus vitulli. Research Square, 1 (22). doi: http://doi.org/10.21203/rs.3.rs-257651/v1

[10] Shevchenko, A., Slobodian, R. (2017). Efficiency of different techniques of cattle treatment with insecticides. EUREKA: Health Sciences, 5, 69-76. doi: http://doi.org/10.21303/2504-5679.2017.00402

[11] Tadesse, A., Fentaw, E., Mekbib, B., Abebe, R., Mekuria, S., Zewdu, E. (2011). Study on the prevalence of ectoparasite infestation of ruminanats in and around Kombolcha and damage to fresh goat pelts and wet blue (pickled) skin at Kombolch Tannary, Northestern Ethiopia. Ethiopian Veterinary Journal, 15 (2), 87-101. doi: http://doi.org/10.4314/evj.v15i2.67697

[12] Musa, S., Ahmed, T., Khanum, H. (2018). Prevalence of ectoparasites in cattle (Bos indicus) of Jessore, Bangladesh. Bangladesh Journal of Zoology, 46 (2), 137-145. doi: http://doi.org/10.3329/bjz.v46i2.39047

[13] Pulotov, F. S., Sayfiddinov, B. F. (2021). Epizootology Bovicolosis of Cattle. International Journal of Progressive Sciences and Technologies, 25 (1), 128-132. doi: http://doi.org/10.52155/ijpsat.v25.1.2800 
[14] Nahorna, L. V., Proskurina, I. V. (2019). Biological and ecological characteristics by agents of entomozes a cattle. Naukovo-tekhnichnyi biuleten instytutu biolohii tvaryn i DNDKI vetpreparativ ta kormovykh dobavok, 20 (1), 139-144.

[15] Gharbi, M., Ben Abdallah, H., Mbarek, Y., Jedidi, M., Darghouth, M. A. (2013). Cross-sectional study of cattle lice infestation in the region of Nabeul in north-east Tunisia. Revue Scientifique et Technique de l'OIE, 32 (2), 879-883. doi: http://doi.org/ 10.20506/rst.32.2.2208

[16] Mehlhorn, H., Al-Rasheid, K. A. S., Abdel-Ghaffar, F., Klimpel, S., Pohle, H. (2010). Life cycle and attacks of ectoparasites on ruminants during the year in Central Europe: recommendations for treatment with insecticides (e. g., Butox $\left.{ }^{\circledR}\right)$. Parasitology Research, 107 (2), 425-431. doi: http://doi.org/10.1007/s00436-010-1957-0

[17] Kebede, N., Fetene, T. (2012). Population dynamics of cattle ectoparasites in Western Amhara National Regional State, Ethiopia. Journal of Vet. Med. and Animal Health. 4(1). 22-26.

[18] Melnychuk, V. V., Kovalenko, S. O. (2021). Klinichnyi proiav bovikoloznoi invazii u velykoi rohatoi khudoby. Implementation of scientific foundations in practice. Turin, 154-156.

[19] Blagoveschenskiy, D. I. (1972). Metody issledovaniya vshey. Leningrad: Nauka, 58.

[20] Perekrestov, V. I. (2014). Praktychni metody elektronnoi mikroskopii. Sumy, 241.

Received date 04.06.2021

(C) The Author(s) 2021

Accepted date 16.07.2021

Published date 30.07.2021

This is an open access article under the Creative Commons CC BY license

How to cite: Proskurina, I., Nahorna, L. (2021). Study of biological and ecological features of permanent ectoparasites of cattle. EUREKA: Health Sciences, 4, 101-108. doi: http://doi.org/10.21303/2504-5679.2021.001965 